\title{
The British Army and the Problem of Venereal Disease in France and Egypt during the First World War
}

\author{
MARK HARRISON*
}

In his biography of one of the Great War's best-known generals, Sir George Arthur ventured that

It is not to peer too intrusively into the arena of a man's life to allude to its austere purity, to suggest that in this respect there are men of high courage who shrink back with something like horror from certain forms of evil, to whom it would be a shame even to speak of those things done in secret ... He looked, of course, for no moral Utopia but no name, nor effort, was subscribed more heartily than his to the famous Memorandum in which officers were urged to encourage in their men a belief in leading a good and healthy life, and in every way-not least by themselves setting an example of self-restraint-to protect them from a grave and devastating evil. ${ }^{1}$

Arthur wrote not of the saintly Kitchener, that old warhorse of the British purity movement, ${ }^{2}$ but of Field-Marshal Haig, Commander-in-Chief of British forces in France. Can this be the same man who stood near the apex of a military élite which, we are told, "defended the belief that army morale was contingent on sexual activity" and which was "quite intolerant of any moral arguments on sexual promiscuity" ${ }^{3}$ I do not wish to imply that one assessment is "right" and the other "wrong", but to draw attention to the differing standpoints which existed in the Army on the question of sexual morality and, in particular, on the prevention of sexually-transmitted diseases (then known as "venereal diseases"). Although the Army had, of course, a unique perspective on the problem of venereal disease, it had never spoken with one voice on the subject, which was as hotly debated within the Army, as it was in British public life.

*Dr Mark Harrison, Department of Historical and Visual Studies, Sheffield Hallam University, Psalter Lane, Sheffield S11 8UZ.

The author acknowledges with gratitude the support of the Wellcome Trust. This article has also benefited greatly from the comments of Michael Worboys, Michael Neve, the anonymous referees, and those who attended a seminar based on this article at the Wellcome Institute in May 1994. In addition, I would like to thank Mary Spongberg for allowing me to read her unpublished manuscript, 'The sick rose', cited below.
1 George Arthur, Lord Haig, London, Heinemann, 1928, pp. 50-1.

2 On Kitchener and sexual purity see, Philip Magnus, Kitchener: portrait of an imperialist, London, John Murray, 1958; Philip Warner, Kitchener: the man behind the legend, London, Hamish Hamilton, 1985, pp. 155-7; Ronald Hyam, Empire and sexuality: the British experience, Manchester University Press, 1991, pp. 14, 38-9, 46, 49, 65 .

${ }^{3}$ Bridget A Towers, 'Health education policy 1916-1926: venereal disease and the prophylaxis dilemma', Med. Hist., 1980, 24: 70-87. 


\section{Mark Harrison}

But this article is concerned only indirectly with the politics of VD control in Britain, which have already received a good deal of attention from historians. ${ }^{4}$ Its focus is, rather, the British Army overseas, in its two largest concentrations, in Egypt and France. The ways in which the Army responded to the problem of VD in these countries reveals much about the place of medicine in British warfare. It also illuminates military concepts of masculine virtue, as well as prevalent attitudes towards women, "race", and class. While some of these attitudes were reinforced during the First World War, the widespread incidence of VD challenged many traditional assumptions and, like "shell-shock", posed conceptual, as well as managerial problems. ${ }^{5}$

The British Army's campaign against VD was symptomatic of the ambivalence of its top brass towards technologies developed prior to, or during, the war. ${ }^{6}$ As Tim Travers has argued, the British High Command was slow to emerge from a Victorian military paradigm that valued morale over machines, and which insisted on centralized control as opposed to the exercise of independent judgement by officers and men in the field. ${ }^{7}$ While many new technologies were taken on board by the British Army, those that threatened to disturb the traditional paradigm of warfare (such as tanks and machine guns, which implied the need for greater decentralization) were never fully integrated into British tactics during the First World War.

\footnotetext{
4 The politics of VD in wartime Britain are discussed in the following works: Samuel Hynes, $A$ war imagined: the first world war and English culture, London, Pimlico, 1972, pp. 58-60; Edward $\mathrm{H}$ Beardsley, 'Allied against sin: American and British responses to venereal disease in world war I', Med. Hist., 1976, 20: 189-202; Suzann Buckley, 'The failure to resolve the problem of venereal disease among the troops in Britain during world war I', in Brian Bond and Ian Roy (eds), War and society: a yearbook of military history, vol. 2, London, Croom Helm, 1977, pp. 65-85; Edward J Bristow, Vice and vigilance: purity movements in Britain since 1700, Dublin, Gill \& Macmillan, 1979; Jay Winter, The great war and the British people, London, Macmillan, 1985, pp. 177, 211; Jeffrey Weeks, Sex, politics, and society: the regulation of sexuality since 1800 , London and New York, Longman, 1989; Richard Davenport-Hines, Sex, death and punishment: attitudes to sex and sexuality in Britain since the Renaissance, London, Collins, 1990; Lesley A Hall, Hidden anxieties: male sexuality, 1900-1950, Cambridge, Polity Press, 1991; Arthur Marwick, The deluge, 2nd ed., Basingstoke, Macmillan, 1992, pp. 145-52; S M Tomkins, 'Palminate or permanganate: the venereal prophylaxis debate in Britain, 1916-1926', Med. Hist., 1993, 37: 382-98.

5 On "shell-shock" see Martin Stone, 'Shellshock and the psychologists', in W F Bynum, $\mathrm{R}$ Porter and $\mathrm{M}$ Shepherd (eds), The anatomy of madness: essays in the history of psychiatry, vol. 2, Institutions and society, London and New York,
}

Tavistock, 1985, pp. 242-71; Peter J Lynch, 'The exploitation of courage: psychiatric care in the British army, 1914-1918', MPhil thesis, University of London, 1977; Elaine Showalter, The female malady: women, madness, and English culture, 1830-1980, New York, Pantheon, 1985, pp. 167-94; Daniel Pick, Faces of degeneration: a European disorder, c. 1848-c.1918, Cambridge University Press 1989, pp. 228-32.

6 The British Army was not untypical in this respect. New technology was resisted in other armed forces whenever it threatened to alter established systems of command and control. See Susan J Douglas, 'Technological innovation and organizational change: the Navy's adoption of radio, 1899-1919', in Merrit Roe Smith (ed.), Military enterprise and technological change: perspectives on the American experience, Cambridge, Mass., MIT Press, 1985, pp. 117-73.

7 Tim Travers, The killing ground: the British army, the western front and the emergence of modern warfare 1900-1918, London, Unwin Hyman, 1990; idem, How the war was won: command and technology in the British army on the western front 1917-18, London, Routledge, 1992. A similar point is made in John Terraine's The smoke and the fire: myths and anti-myths of war 1861-1945, London, Leo Cooper, 1992, chs 14 and 16. For a comparison with the German Army's use of technology see Michael Geyer, 'The German practice of war, 1914-1945', in G Craig, F Gilbert and P Paret (eds), Makers of modern strategy, Princeton University Press, 1986, pp. 527-97. 
Although Travers may have underestimated the extent to which the British High Command was innovative during the Great War, his observations help us to make sense of military attitudes towards VD control. For although the High Command generally embraced medicine as a means of improving manpower efficiency, and encouraged the development and diffusion of new medical technologies, ${ }^{8}$ there were some important exceptions. The control of venereal disease was seen as a "moral" as much as a "medical" problem, and "moral" considerations loomed large in traditional notions of discipline and military honour. For many officers of the old school, "morality" and "efficiency" went hand in hand, and they viewed with suspicion those strategies of VD control which seemed to undermine their idea of military virtue. But many reform-minded medical and combatant officers regarded such notions as an impediment to military efficiency, and sought to place VD control on a more "scientific" and "realistic" footing. Advocates of "moral policing" were also confronted with the uncomfortable fact that officers and chaplains - the supposed bastions of military virtue-were as prone to temptation as the humblest ranker.

The debate over VD control in the British Army was not, however, conducted in isolation: competing elements within the Army formed alliances with like-minded civilian groups involved in the campaign against VD. Indeed, military men were themselves prominent in, or closely associated with, these organizations. Outside of the UK, it was also necessary for the Army to come to terms with foreign governments and influential civilians, and the different political circumstances which obtained in France and Egypt meant that VD control in those countries proceeded along very different lines.

\section{The Legacy of the Contagious Diseases Acts}

The British attempt to control VD during the First World War can be fully understood only when viewed in the light of the notorious Contagious Diseases (CD) Acts. The Acts, which established a system of medically-regulated prostitution in Britain between 1864 and 1886, had their roots in military reforms following the Crimean War and in anxieties about a possible invasion by the French. A steady rise in VD in the British forces during the first half of the nineteenth century called into question the absence of controls over prostitution and the sexual activities of soldiers; especially since a system of regulation had been introduced in several Continental countries. ${ }^{9}$ However, as is well known, the Acts were opposed by many of those who otherwise embraced sanitary legislation, and were repealed following a vigorous campaign by religious organizations, political radicals and opponents of state intervention. A successful campaign was conducted against similar legislation in India, where up to one-third of the British Army was garrisoned prior to $1914 .^{10}$

${ }^{8}$ See Steve Sturdy, 'From the trenches to the hospitals at home: physiologists, clinicians and oxygen therapy, 1914-30', in J V Pickstone (ed.), Medical innovations in historical perspective, London, Macmillan, 1992, pp. 104-23; Roger Cooter, 'War and modern medicine', in W F Bynum and R Porter (eds), Companion encyclopedia of the history of medicine, London and New York, Routledge, 1993, pp. 1536-73.

${ }^{9}$ On the CD Acts see F B Smith, 'Ethics and disease in the late-nineteenth century: the Contagious Diseases Acts', Hist. Stud., 1971, xv: 118-35; idem, 'The Contagious Diseases Acts reconsidered', Soc. Hist. Med., 1990, 3: 197-215; Bristow, op. cit., note 4 above, pp. 78-84; Judith R Walkowitz, Prostitution and Victorian society: women, class and the state, Cambridge University Press, 1980, pp. 48-76; Hyam, op. cit., note 2 above, ch. 6.

${ }^{10} \mathrm{~F}$ W Perry, The colonial armies, Manchester University Press, 1990, pp. 82-6. 


\section{Mark Harrison}

At first, the CD Acts had the whole-hearted support of the military top-brass, including the medical departments of the Army and Navy. Indeed, senior medical officers such as John Liddell, Director General of the Naval Medical Service, were among the foremost proponents of regulation. ${ }^{11}$ In India the desire to control prostitution was even stronger, and a system of regulation had operated (at different times and in different places) since the turn of the nineteenth century. Legislation on the lines of the British CD Acts was introduced in 1866, and was maintained until 1888 despite opposition from civil administrators and prominent Indians. Even after its repeal, the practice of regulated prostitution continued semi-officially under deliberately vague clauses of cantonment legislation which permitted the hospitalization of persons suspected of having an "infectious disease". ${ }^{2}$ Similar arrangements were made for the protection of British servicemen in other British colonies and naval stations. ${ }^{13}$

Why were the military authorities so determined to maintain a system of regulated prostitution? There is no clear-cut evidence that the CD Acts had any appreciable effect on the incidence of VD in the armed forces. The Continental system upon which the British legislation was modelled was no stunning success, and it has been claimed that some military commanders were aware of this even before the enactment of legislation in Britain. ${ }^{14}$ The introduction of regulated prostitution coincided with a decrease in VD in the British Army but there was much scepticism about the causal role of the legislation; and, in India, admissions to hospital from VD actually rose under the CD Acts, reaching a peak in 1895. Throughout this period, a number of Army medical officers together with organizations such as the National Medical Association for the Repeal of the Contagious Diseases Acts, questioned the efficacy of regulation and recommended its curtailment, if not its abolition. ${ }^{15}$

But the majority of military and medical men held the view that the female body, and especially that of the prostitute, was an infectious site which needed to be policed just as drains and sewers needed to be policed. Such views were deeply ingrained and did not rest on medical "evidence" alone. ${ }^{16}$ The Acts also formed part of a more general attempt to regulate contact between civilian and military domains. As Myna Trustram has shown, the regulation of prostitution, and the exclusion of women from certain spheres of military life, was bound up with the professionalization of the armed forces during the mid-Victorian period. ${ }^{17}$ Contact with civilians-and particularly "undesirable"

11 Walkowitz, op. cit., note 9 above, p. 76.

12 Kenneth Ballhatchet, Race, sex and class under the Raj: imperial attitudes and policies and their critics, London, Weidenfeld \& Nicolson, 1980; David Arnold, Colonizing the body: state medicine and epidemic disease in nineteenth-century India, Berkeley, California University Press, 1993, pp. 83-7; Mark Harrison, Public health in British India: Anglo-Indian preventive medicine, Cambridge University Press, 1994, pp. 72-6; Philippa Levine, 'Venereal disease, prostitution, and the politics of empire: the case of British India', J. Hist. Sexuality, 1994, 4: 579-602.

${ }^{13}$ Hyam, op. cit., note 2 above; Jean Kehoe, 'Medicine, sexuality, and imperialism. British medical discourses surrounding venereal disease in
New Zealand and Japan: a socio-historical and comparative study', PhD thesis, Victoria University of Wellington, 1992.

14 Bristow, op. cit., note 4 above, pp. 78-9.

15 Harrison, op. cit., note 12 above, pp. 72-6. The significance of the NMA and medical arguments in favour of repeal has probably been underestimated: see Mary Spongberg, 'The sick rose: constructing the body of the prostitute in nineteenth century British medical discourse', $\mathrm{PhD}$ thesis, University of Sydney, 1993, pp. 109-31.

16 Spongberg, ibid., pp. 81-108.

17 Myna Trustram, Women of the regiment: marriage and the Victorian army, Cambridge University Press, 1994. 


\section{The British Army and Venereal Disease during the First World War}

elements-exposed soldiers to inappropriate habits and values, as well as to VD. Prostitution was associated not only with disease but with intemperance and disorder. ${ }^{18}$

Regulation, however, was but one part of the Army's campaign against VD. From the middle of the nineteenth century, the British soldier became a target for moral reformers, of whom Florence Nightingale is the best-known example. The ordinary soldier was no longer seen as fundamentally depraved but as amenable to moral improvement. Before long, upright military figures such as General Gordon came to epitomize the new "muscular" Christianity. And from this "Christian militarism", as Olive Anderson has termed it, ${ }^{19}$ arose a new concept of masculinity which stressed the virtues of chivalry, physical fitness and sexual continence. Self-restraint was also part of the Stoical, neoSpartan ethos emerging in some public schools, while the tenets of "Social Darwinism" provided a materialistic basis for strictures on physical purity. ${ }^{20}$ These moral and biological imperatives were easily assimilated into the outlook of British military commanders who had long valued discipline and morale over technical competence. It was widely held that rational control over body and mind helped to prepare young men for the conduct expected of them on the battlefield. ${ }^{21}$

After 1860, exhortations to sexual continence began to appear in hygiene manuals alongside more familiar appeals for temperance in diet and alcohol consumption. As opposition to the CD Acts mounted, more emphasis was placed on rational and uplifting recreation for soldiers. Army camps were provided with skittle alleys, workshops, libraries and gymnasia, and the soldier's entitlement to alcohol was reduced. At the same time, a more tolerant attitude towards the marriage of soldiers was emerging, for it was hoped that marriage would discourage more casual liaisons. ${ }^{22}$

18 Such an interpretation is borne out by the discriminatory way in which regulation was enforced in Continental countries. Here the primary concern in civil life as in the armed forces was the maintenance of order. Hence, those prostitutes who plied their trade discreetly, in a way which did not offend public decency, were generally exempt. See Abraham Flexner, Prostitution in Europe, London, Grant Richards, 1919, pp. 208-9.

19 Olive Anderson, 'The growth of Christian militarism in mid-Victorian Britain', Engl. hist. Rev., 1971, 86: 46-72. See also Stephen Koss,

'Wesleyanism and empire', Hist. J., 1975, 18: 105-18.

20 Concepts of masculinity in Victorian and Edwardian Britain are discussed in Bruce Haley, The healthy body and Victorian culture, Cambridge, Mass., Harvard University Press, 1978; J A Mangan, Athleticism in the Victorian and Edwardian public school: the emergence and consolidation of an educational ideology, Cambridge University Press, 1981; J A Mangan and J Walvin (eds), Manliness and morality: middle-class masculinity in Britain and America, 1880-1940, Manchester University Press, 1987; Norman Vance, The sinews of spirit: the ideal of Christian manliness in Victorian literature and religious thought, Cambridge University Press, 1985; Allen Warren, 'Citizens of the empire: Baden-Powell, scouts and guides and an imperial ideal, 1900-40', in J M MacKenzie (ed.), Imperialism and popular culture, Manchester University Press, 1986, pp. 233-56.

21 See Frank Mort, Dangerous sexualities: medico-moral politics in England since 1830, London and New York, Routledge \& Kegan Paul, 1983 , p. 194. Several classic psychological studies have listed sexual prudery among the distinguishing features of the "authoritarian personality": see T W Adorno, et al., The authoritarian personality, New York, Harper, 1950. It is claimed that such figures as Haig and Kitchener exhibited certain "authoritarian" characteristics, although they by no means fit easily into Adorno's category: see Norman F Dixon, On the psychology of military incompetence, London, Futura, 1991 ed., pp. 369-92.

22 Julius Jeffreys, The British army in India: its preservation by an appropriate clothing, housing, locating, recreative employment, and hopeful encouragement of the troops, London, Longman, Brown, Green, Longmans \& Roberts, 1858; Charles Alexander Gordon, Army hygiene, London, John Churchill \& Son, 1866; J Cole, Notes on hygiene with hints on self-discipline for young soldiers in India, Calcutta, Sanawar, 1882; Alan R Skelley, The Victorian army at home: the recruitment and terms and conditions of the British regular, 1859-1899, London, Croom Helm, 1977. 


\section{Mark Harrison}

Immediately before and during the First World War, the emphasis on morality and selfrestraint was still very much in evidence in military literature on VD. The watchwords of H K Allport's Health memoranda for soldiers, published in 1910, were "Cleanliness, moderation, pure air and self-control". ${ }^{23}$ Sexual purity was also prominent in Major $\mathbf{H}$ Waite's Soldiers' guide to health of 1915, in which he argued that desire could be overcome by "avoiding impure conversation, thought, and temptation" and "by regular employment of muscular and mental exercises". ${ }^{24}$ Such advice was common in military texts on hygiene prior to $1914,,^{25}$ and continued to play an important part in forming official attitudes towards the problem of VD during the war. Lord Kitchener's famous appeal to the British Expeditionary Force (BEF) in 1914 called upon his men to "keep constantly on your guard against any excesses. In this new experience you may find temptations both in wine and women. You must entirely resist both temptations and while treating women with perfect courtesy, you should avoid any intimacy". ${ }^{26}$ Kitchener, then, was no isolated monument to Victorian morality. His appeal to self-restraint was in keeping with the general tenor of military thinking at the time, which continued to uphold Victorian ideas about the importance of character and morale in military efficiency. ${ }^{27}$

By 1914, however, there were signs that a new attitude towards VD control was emerging in the British Army. In 1910 the Army Medical Advisory Board-composed of both civilian and military medical men-recommended that effective treatment be provided under conditions to which no penal stigma was attached. ${ }^{28}$ And medical treatment came increasingly to the fore in discussions about VD control during the next few years, following successful trials with the anti-syphilis drug Salvarsan at the Rochester Row Military Hospital in $1911 .^{29}$ The same was true of medical prophylaxis, developed by the Paris-based bacteriologists Elie Metchnikoff and Émile Roux from 1906. They claimed that syphilis could be prevented by the prophylactic use of disinfectants such as calomel ointment and permanganate of potash. ${ }^{30}$ Prophylaxis was introduced on an experimental basis in the United States Army as early as $1910^{31}$ but it was to prove far more controversial in Britain, for the procedure seemed to sanction the very behaviour which commanders had previously sought to discourage.

\footnotetext{
${ }^{23}$ H K Allport, Health memoranda for soldiers, London, HMSO, 1910, p. 20.

24 H Waite, How to keep "fit" or the soldiers' guide to health in war and peace, London, Gale \& Polder, 1915, pp. 46-7.

25 See E C Freeman, The sanitation of British troops in India, London, Rebman, 1899; Robert Caldwell, Military hygiene, London, Ballière, Tindall \& Cox, 1905; R K Firth, Military hygiene: $a$ manual of sanitation for soldiers, London, Churchill, 1908; T W Gibbard, Notes on sanitation in barracks and camps for officers and noncommissioned officers, Lahore, Civil and Military Gazette, 3rd ed., 1906.

${ }^{26}$ Kitchener's appeal was stuck onto the Active Service Paybooks of soldiers in the BEF.
}

27 Travers, op. cit., note 7 above.

28 Advisory Board for the Army Medical Services, Final report of venereal diseases and scabies in the army, London, HMSO, 1910, p. 2.

29 See the Local Government Board's Report on venereal diseases, London, HMSO, 1913. For the trials at Rochester Row see T W Gibbard and L W Harrison, 'Observations on the use of salvarsan in syphilis', Lancet, 1911, i: 726-31; idem, 'Further observations on the use of salvarsan in syphilis', J. Royal Army Med. Corps, 1911, 16: 351-75.

30 Tomkins, op. cit., note 4 above, p. 384; P.P. 1916, xvi, Cd. 8189, Royal Commission on Venereal Diseases, Final report of the commissioners, p. 59.

31 Beardsley, op. cit., note 4 above, p. 196. 


\section{France}

When war broke out, there were three relatively distinct positions on VD control in the British Army: sexual continence; medically-regulated prostitution; and a more liberal approach associated with new technologies of prevention. All of these were reflected to varying degrees in the system of VD control established in France. In keeping with the emphasis of military hygiene prior to 1914, and Kitchener's address to the BEF, considerable effort was made to "attract officers and men to pleasing and health-giving recreation" during their off-duty hours. Organized sport and other efforts aimed to provide positive distractions, while punitive measures were enforced as disincentives to contact with the opposite sex. Any soldier admitted to hospital with VD (or alcoholrelated complaints) faced a stoppage of pay and no leave for twelve months. In addition, there were humiliating random inspections for VD (so-called "dangle parades") in which men would be compelled to drop their trousers in front of officers and NCOs. ${ }^{32}$ Heavy reliance was also placed on lectures organized by the National Council for the Combatting of Venereal Disease. ${ }^{33}$ The NCCVD, set up following the Report of the Royal Commission on VD in 1916, drew attention to the medical consequences of promiscuity, but within a strongly moral framework. This overriding concern with "moral conduct" was also present in the lectures given by Army chaplains and medical officers, an approach which had the support of many senior officers (some of whom were members of the NCCVD and other purity organizations in Britain). ${ }^{34}$

All this seems to suggest that the British High Command was less tolerant of sexual activity in the Army than is generally assumed. Indeed, as the young officer, P G Heath, recalled:

Venereal disease was dealt with on lines that were, presumably, a relic of the Victorian Age. The idea seemed to be that sex was a matter which played no part at all in the soldier's way of life. At long intervals, a MO ... would deliver a lecture on the dangers to be encountered by frequenting "loose women". These exhortations, if acted upon, would have condemned the men to a monastic existence for the duration of the war... The padres who, I fear, had little practical knowledge of the subject, would carry on the good work by delivering improving discourses about "clean living", "manly Christianity", and so on. The Army, doubtless considering that they had done all in their power to deal with this menace, issued no prophylactics to the men, and should any of them develop venereal disease they were treated as social pariahs; thus should a man be returned cured after treatment in a venereal disease hospital, his name was promptly placed at the bottom of the leave roster. ${ }^{35}$

The Army also notified a VD patient's next of kin of his admission into hospital and of the nature of his complaint. The procedure was abandoned in 1916 after a Major

32 See John Ellis, Eye-deep in hell: the western front 1914-18, Abingdon, Purnell, 1976, pp. 152-3; Dennis Winter, Death's men: soldiers of the great war, London, Penguin, 1979, pp. 150-2; Peter Simkins, 'Soldiers and civilians: billeting in Britain and France', in I Beckett and K Simpson (eds), $A$ nation in arms: a social study of the British army in the first world war, London, Tom Donovan, 1985, pp. 184-6.

${ }^{33}$ The NCCVD gave a total of 1,956 lectures to $1,621,943$ troops in the UK during the war. It also provided special instruction for officers entering the RAMC. See W G MacPherson, W P Herringham, T R Elliott and A Balfour (eds), History of the great war based on official documents: diseases of the war, vol. 2, London, HMSO, 1923, p. 121.

34 Imperial War Museum (IWM) 66/96/1: correspondence of Revd M A Bere to his wife and children; letter of 25 April.

35 IWM DS/misc/60: the First World War memoirs of P G Heath, pp. 377-8. 


\section{Mark Harrison}

committed suicide on hearing that his wife had been informed. Thereafter, a soldier's family was told that he had been admitted for some disease that had not yet been diagnosed. ${ }^{36}$

VD hospitals (established from 1915$)^{37}$ were often regarded, if not intended, as deterrents in themselves. Intensive treatment with Salvarsan substitutes and mercurythough reasonably successful ${ }^{38}$ —often had unpleasant and sometimes serious sideeffects, such as convulsions and jaundice. ${ }^{39}$ The treatment of gonorrhoea by the irrigation method was similarly painful and undignified:

he [the patient] is placed lying on his back on a table, with his legs apart ... The glans and prepuce are thoroughly cleansed, the douche-can is raised about $2 \mathrm{ft}$. above the patient's pelvis, an assistant turns the stopcock, and a gentle stream of the irrigating solution is allowed to flow ... The surgeon then inserts the nozzle . . . into the urinary meatus, and the anterior urethra is thoroughly washed out ... By means of percussion and by heeding the patient's sensations one can tell when the bladder is full. ${ }^{40}$

Such procedures were understandably unpopular with VD patients. When asking for volunteers to take part in trials to determine the most effective method of treating gonorrhoea, the RAMC officers H C Donaldson and A M Davidson found that all their patients opted for chemical therapy instead of irrigation. ${ }^{41}$ Patients also claimed that doctors in VD hospitals were inattentive, and that orderlies were too often callous and slovenly. ${ }^{42}$

During their long stay in hospital-the average duration being between 50 and 60 days ${ }^{43}$ - patients were also subjected to the unwelcome attention of the hospital chaplain. The Revd M A Bere made a special point of talking privately to VD cases whenever he had the opportunity. He was seldom harsh or judgemental but sought to appeal to the patient's higher nature during intimate conversation. The following comment is typical: "We have one of our patients in bed with a chill, so I shall be able to see a good bit of him. He is an awfully nice lad, once a chorister, but it is awkward not having a tent to oneself in which to talk to a fellow of that sort". ${ }^{44}$ However, not even chaplains were immune to temptation, and the sight of them as patients in VD hospitals was a source of great amusement to the troops. ${ }^{45}$

Yet VD hospitals were not always such unappealing places. Entertainments were sometimes provided for the patients, and the staff were often sympathetic. J S Ware, a

36 Ibid., p. 379.

37 MacPherson, et al., op. cit., note 33 above, pp. 130-1. The prototype VD hospital was No. 9 VD Hospital established at Rouen in 1915 under Major L W Harrison. It was one of 4 large VD hospitals in France, with an additional 4 smaller units, providing a total of 9,000 beds. Another 1,000 beds in specialist VD hospitals were provided in Egypt and 11,000 in the UK.

38 MacPherson, et al., op. cit., note 33 above, p. 135. The vast majority of those treated in VD hospitals were eventually returned to the Front: No. 9 VD Hospital treated almost 71,000 patients between 1915 and 1918 , only 453 of whom were invalided back to the UK.
39 See T F Ritchie, 'The treatment of venereal disease in armies', Int. J. Publ. Health, 1921, 2: 61.

40 E T Burke, 'The treatment of gonorrhoea in a field ambulance', Lancet, 19 May 1917, i: 756-58.

${ }^{41}$ H C Donald and A M Davidson, 'The medicinal treatment of gonorrhoea', Br. med. J., 1917, ii: 512-13.

42 Memoirs of P G Heath, op. cit. note 35 above, p. 379.

43 MacPherson, et al., op. cit., note 33 above, pp. 153-5.

44 Correspondence of Revd M A Bere, op. cit., note 34 above, letters of 11 April and 27 June 1918.

45 Ibid., letter of 4 December 1917; Robert Graves, Goodbye to all that, London, Penguin, 1983 ed., p. 195. 
YMCA welfare officer at No. 9 VD Hospital near Le Havre, claimed to have enjoyed friendly relations with the patients and made good reports of the medical staff. Moreover, a spell in a VD hospital, despite the attendant punishments, was still viewed as preferable to life in the trenches. Ware recorded in his diary a speech given by another YMCA officer on leaving the hospital:

He boldly said that, whereas some of the old Army came to France from India, already venereal, others deliberately risked contracting one of the two diseases, hoping by this "self-inflicted wound" to win a respite from the trenches ... There was no protest from the men. Perhaps they knew it was true of some of them: the authorities certainly believed it. ${ }^{46}$

It was generally acknowledged that VD was sometimes contracted to secure a stay in hospital, ${ }^{47}$ and the opportunities for doing so were considerable. Although trench warfare restricted sexual activity, men were able to compensate for their enforced abstinence by visiting brothels whilst on leave in Britain and France. ${ }^{48}$ However, the extent to which British soldiers resorted to prostitutes is unclear. Despite the anonymity conferred by war service abroad, some British soldiers were reluctant to patronize brothels for moral reasons, because of their squalidness, or because they feared the stigma of VD. ${ }^{49}$ Ironically, some contracted VD from girls with whom they believed they enjoyed monogamous and loving relationships. ${ }^{50}$ But with the ever-present spectre of death, the majority of men probably had no such qualms; as W H Auden put it, "In times of war even the crudest kind of positive affection between persons seems extraordinarily beautiful". 51 According to Robert Graves: "There were no restraints in France; these boys had money to spend and they knew they stood a good chance of being killed within a few weeks anyhow. They did not want to die virgins". 52 However, many were not virgins, especially working-class lads who were more sexually experienced and, we are told, less troubled by pangs of conscience than their middle-class comrades. ${ }^{53}$

But if British officers overseas had ever conformed to the codes of sexual conduct expected of them, the Great War had a levelling effect as far as sexual morality was concerned. Captain L Gameson, RAMC, recalled that many officers had "wantonly abandoned caste", and remembered one fellow medical officer who had "virtually lived with a whore, at her brothel in Lille". He believed that promiscuity was common among

46 IWM P. 44: papers of J S Ware; diary entry of 28 November 1915.

${ }^{47}$ Burke, op. cit., note 40 above, p. 756.

48 Alain Corbin, Women for hire: prostitution and sexuality in France after 1850, trans. Alan Sheridan, Cambridge, Mass., and London, Harvard University Press, 1990, pp. 334-5.

49 IWM P. 185: Alex Runcie, 'Territorial Mob', unpublished account c. 1960; IWM P. 126, A Surfleet, 'Blue chevrons: an infantry private's great war diary', unpublished account, c. 1962; based on diaries kept during 1916-17. The stigma of VD and the ugliness of many brothels is also discussed in Hall, op. cit., note 4 above, pp. 35-7, 49-50.

50 Papers of J S Ware, op. cit., note 46 above, diary entry of 18 November 1915 .
51 Quoted in Paul Fussell, The great war and modern memory, Oxford University Press, 1975, p. 270 .

52 Graves, op. cit., note 45 above, p. 195. These sentiments were echoed by many French soldiers, see Stéphane Audoin-Rouzeau, Men at war 1914-1918: national sentiment and trench journalism in France during the first world war, trans. Helen McPhail, Providence, RI, and Oxford, Berg, 1992, pp. 128-34.

53 John Baynes, Morale: a study of men and courage. The Second Scottish Rifles at the battle of Neuve Chapelle, 1915, London, Cassell, 1967, p. 212. 


\section{Mark Harrison}

all ranks, in both the British and German armies, and Gameson admitted that medical warnings did little to curb the sexual appetites of the young officers with whom he came into contact:

I walked one night the length of the Rue Nationale with a young officer practically a stranger to me. He had suddenly confessed he wished to be guided on the subject of promiscuity by a straight talk with an M.O. . . . So during our leisurely stroll, I tried to cover the ground from various points of view as well as the obvious one of venereal disease. Several times on the way he said: "Doc., you're right. Thank goodness I've talked to you" ... We had almost reached the long street's end, when a girl brushed past us and murmured to him a soft "Hullo". He left me abruptly, then called over his shoulder: "Sorry, Doc. It's no use. See you another day".

Shortly afterwards Gameson surrendered his own virginity, which he had carefully preserved throughout his four years in France. ${ }^{54}$

\section{Maisons de Tolérance}

Prostitution in France was conducted by a growing number of "amateurs", like the one encountered by Gameson's young officer, as well as by women in licensed houses known as maisons de tolérance. Licensed or "regulated" prostitution had existed in France since the mid-nineteenth century. It was based on the widespread belief that prostitution was inevitable and even socially necessary, but that it should be closely supervised with a view to preventing its worst excesses. In the hierarchical milieu of the licensed brothel, prostitutes were subjected to strict discipline by their madame, as well as to regular medical inspections. Moreover, the brothel kept these socially marginal women off the streets, thus preventing the "corruption" of men who would not normally be tempted into such establishments. In the years before the war, this system had fallen into disuse, as the authorities came to favour a "non-custodial" system of registration and medical inspection. The outbreak of war, however, gave a new lease of life to the maisons because of a noticeable increase in unlicensed prostitutes and soliciting in public places. There was also great anxiety about VD in the French Army and about the effects of syphilis on the next generation. By the end of the war there were almost one million admissions to hospital from VD in the French Army. ${ }^{55}$ These concerns led to the establishment of new licensed brothels in 1915, and within two years there were 137 such establishments in 35 towns throughout France. ${ }^{56}$

It is generally thought that British Army commanders took a relaxed view of their men attending maisons de tolérance, believing morale to be dependent upon sexual activity. This was certainly true of many officers, but there were some who strongly disapproved. P G Heath recalled an episode in 1918 which he thought typical of prevailing attitudes among the British and French High Commands:

54 IWM P. 395-7: First World War Papers of Capt. Lawrence Gameson, RAMC, pp. 392-3, 410, 421-2.

55 Corbin, op. cit., note 48 above.

56 Abraham Flexner, I remember: the autobiography of Abraham Flexner, New York, Simon \& Schuster, 1940, pp. 194-8; idem, op. cit., note 18 above, pp. 111-32, 171-209; Paul Faivre, 'Prophylaxie des maladies vénériennes', Revue d'Hygiène et de Police Sanitaire, 1917, pp. 675, 678; Public Record Office (PRO) WO 32/5597: Steps taken by French and Canadian armies; Jules Gaudy, 'Les maladies vénériennes à la armée', Archives Médicales Belges, 1917, p. 509. 


\section{The British Army and Venereal Disease during the First World War}

One day, he [Général Sarrail] decided that the morale of his men was declining, and that they were suffering from what the French call "le Cafard" owing to lack of suitable feminine companionship. To remedy this state of affairs, he organised an establishment for the troops; as it were, a branch of Guy de Maupassant's famous Maison Tellier. When all was ready, he wrote to his opposite number, the commander of the British contingent, telling him what had been done and adding that with the approval of his "cher collègue", the establishment would be placed at the disposal of British troops on Tuesdays and Thursdays. The British General was a very fine old gentlemen, but somewhat strait laced: he sent a stiff reply to Général Sarrail, saying that he could not, for one moment, entertain the latter's proposal.

To this, Sarrail replied that the establishment would be opened to British troops on Saturdays as well! 57

Thus, while some British commanders were much opposed to licensed prostitution, the control which they were able to exert over the sexual activities of their troops was clearly limited. As Heath put it, "The officers could always have a day out in such towns as Amiens, Bethune or Poperinghe; and in the French villages, the local farm girls always seemed willing to do their best to solve the men's problems". ${ }^{58}$ In the cities there were two classes of brothel: deluxe maisons patronized by officers (signified by a blue light) and the rather tawdry institutions visited by other ranks (indicated by red lights). Both were inspected twice weekly by French doctors, ${ }^{59}$ although the value of such examinations was spurious. Abraham Flexner, writing of the medical examination of prostitutes in Paris immediately before the war, described a procedure whereby dozens of women paraded past the doctor who used the same spatula for all. He claimed that one doctor examined 25 or 30 girls without changing, washing, or wiping the rubber fingers he wore. ${ }^{60}$ During the war, the deficiencies of the system were frankly admitted by the French authorities. It was acknowledged that while inspection usually revealed syphilitic infection, it was of little use in detecting gonorrhoea. ${ }^{61}$

By 1917, with increasing unease in Britain and the Dominions, and the entry into the war of the United States, the continued operation of regulated prostitution in France was called into question. The United States was opposed to the officially sanctioned system of prostitution in France, and maisons de tolérance were placed off-limits to American troops. Also, any American soldier who contracted VD was liable to a court martial, unless he had previously undergone prophylaxis. The U.S. government bore heavily on the British to demand that the French put an end to the system but the British were reluctant to take further steps. The French Prime Minister, Clemenceau, showed no sign of giving way, and the Army Council was vociferously opposed to any alteration of existing arrangements. ${ }^{62}$

${ }^{57}$ Memoirs of P G Heath, op. cit., note 35 above, pp. 258-9.

58 Ibid., p. 381.

59 Faivre, op. cit., note 56 above, pp. 676, 693.

60 Flexner, op. cit., note 18 above, p. 169.

61 Jean Gouin, 'Prophylaxie des maladies vénériennes dans l'armée Américain', Revue d'Hygiène et de Police Sanitaire, 1918, p. 782.
62 Beardsley, op. cit., note 4 above, p. 197; Allan M Brandt, No magic bullet: a social history of venereal disease in the United States since 1880, New York, and Oxford, Oxford University Press, 1985, pp. 96-115. 


\section{Mark Harrison}

\section{The Campaign against Regulated Prostitution}

In Britain, however, pressure for the abolition of licensed houses was mounting, the campaign against them having been bolstered by revelations that the British Army was operating its own brothels in Le Havre and Cayeux-Sur-Mer. ${ }^{63}$ The Churches protested that they had not sent their young men to the front only to have them thrust into temptation. The Wesleyan Church also claimed that the inhabitants of Cayeux had been enraged by the establishment of a brothel on the main thoroughfare of their town, and called upon Lord Derby, the Secretary of State for War, to put an end to the scandal. ${ }^{64}$ There was a party political dimension too. The Dean of Lincoln urged Christians not to vote for any MP who failed to rally to their cause, ${ }^{65}$ while the Archbishop of Canterbury threatened to raise the matter in the Lords if the government did not take action. ${ }^{66}$ Women's organizations such as the Women's Temperance Association and the Mothers' Union also joined the fray, viewing the measures in France as a revival of the hated CD Acts. ${ }^{67}$

The War Office was caught in the cleft stick of public opinion, on the one hand, and the Army Council-which insisted that regulation continue-on the other. Some military men continued to favour regulation on medical grounds, ${ }^{68}$ but other factors were equally if not more important. The Adjutant-General H J Creedy urged the Secretary of State for War to maintain regulation since "a considerable number of men will have to picket these places if prohibition is not to become a farce". It was feared that enforcement of the regulations would require the diversion of hundreds of men from combatant to police duties. ${ }^{69}$ There were also indications that the incidence of rape and "unbecoming behaviour" towards women had risen markedly following a similar ban placed on U.S. servicemen, while prostitution had moved outside of town centres making effective supervision impossible. ${ }^{70}$

More importantly, the Army Council opposed the closing of brothels to British troops on the grounds that it would offend the French. The French Minister of War and the Governor of Le Havre protested that it would endanger the health of the troops and the civilian population. ${ }^{71}$ The Commander-in-Chief of the BEF, Field Marshal Haig, informed Lord Derby at the end of 1917, "that he was strongly of the opinion that it would be most undesirable that any representations should be made by us to the French authorities with regard to the matter". ${ }^{72}$ Haig, steeped in the teachings of the Scottish

63 Daily News, 13 March 1918; The Shield, 1916-17, pp. 393-7.

64 PRO WO 32/5597: Resolution passed by the Social Purity Committee of the Wesleyan Church, 6 March 1918.

65 PRO WO 32/5597: newspaper cutting of 13 March 1918, source unknown; The Times, 4 March 1918.

66 PRO WO 32/5597: Archbishop to Derby, 16 March 1918.

${ }^{67}$ PRO WO 32/5597: C Longhurst to Adj.-Gen., 11 March 1918; Salisbury to Derby, 21 January 1918.

68 PRO WO 32/5597: Adj.-Gen. to Sec. of State for War, 11 June 1918: "The surrender of the
Government to the clamour of religious sentimentalists who have neither the experience or the knowledge to judge of the effect of their agitation can only result in harm and increased disease throughout the Army".

69 PRO WO 32/5597: Creedy to Sec. of State, 15 March 1918.

70 PRO WO 32/5597: extract from proceedings of the Permanent Board of the Inter-Allied Medical Committee, December 1917.

71 PRO WO 32/5597: proceedings of Cabinet meeting, 18 March 1918.

72 PRO WO 32/5597: Haig to Derby, 29 December 1917. 
Kirk, had no great liking for a system which seemed to condone immorality. His own preference was to encourage sexual restraint, hence his enthusiastic endorsement of Kitchener's appeal to abstinence. ${ }^{73}$

Although regulated prostitution was maintained for political reasons, such as those voiced by Haig, there were a growing number of officers in the field who were pessimistic about the prospects of controlling VD under the existing system. ${ }^{74}$ While VD rates had fallen during 1915-16, and compared favourably with pre-war levels, the total number of those rendered "non-effective" was extremely high, especially in view of acute manpower shortages in the last years of the war. Further, as shown in the Table below, admissions to hospital from VD began to increase again in 1917. However, one needs to treat these figures with some caution since, given the penal stigma attached to VD, many cases may have been concealed, especially at the beginning of the war when next of kin were still being informed. This was certainly the opinion of Captain Gameson, RAMC, who treated many cases secretly within his unit, rather than send them to a VD hospital as he was supposed to. ${ }^{75}$

Table

Admissions to hospital as a result of venereal diseases in the BEF in France and Flanders, 1914-18

\begin{tabular}{ccc}
\hline Year & Admissions & Per '000 Troops \\
\hline 1914 & 3,291 & 17.3 \\
1915 & 17,525 & 29.7 \\
1916 & 24,108 & 18.2 \\
1917 & 48,508 & 25.6 \\
1918 & 60,099 & 32.4 \\
\hline
\end{tabular}

Sources: T J Mitchell and G M Smith, History of the great war based on official documents. Medical services: casualties and medical statistics of war, London, HMSO, 1931, p. 73; A G Butler, The Australian army medical services in the war of 1914-1918, vol. 3, Canberra, Australian War Memorial, 1943, p. 180.

By the spring of 1918, the campaign against regulated prostitution had gained such momentum that it could no longer be ignored. The Parliamentary Under Secretary for War, Ian MacPherson, claimed that the question was now a "national rather than a military one" and that, unless brothels were placed out of bounds, the government would be unable to defend itself in the House of Commons or the country. He added that the French Prime Minister Clemenceau was now willing to let Britain exercise judgement in whichever way it pleased. His superior, Lord Derby, had also been advised by Lord Salisbury that

\footnotetext{
73 On the Scottish Church and sexuality see Kenneth M Boyd, Scottish church attitudes to sex, marriage and the family 1850-1914, Edinburgh, John Donald, 1980.

74 PRO WO 32/5115: Annual Report on Infectious Diseases in France, 1917 (the VD rate for 1917 was between 101 and 198 per 100,000 per month, i.e. over 24,000 cases); Annual Report of the
}

\footnotetext{
Specialist Sanitary Officer, Marseilles Base: "Venereal disease is very prevalent in the town. Prostitution is carried on to an enormous extent, and the number of infected women must be very great. Proper control during the war is impossible."

${ }^{75}$ Papers of Capt. L Gameson, op. cit., note 54 above, p. 410.
} 


\section{Mark Harrison}

Everything depends now upon keeping the people keen about the war but if the notion which has already taken root is allowed to spread that instead of being a sacred cause the war is a vehicle of vice and demoralisation there will arise an uneasiness amongst the soundest part of the people ... that the war is under a curse. It is impossible to exaggerate the danger of such a sentiment.

Despite continued protests from the Army Council, the Cabinet felt it had little option other than to place licensed brothels out of bounds to British troops. ${ }^{76}$

As expected, the ban met with a storm of protest in France, even though it was difficult to enforce in practice. ${ }^{77}$ The War Office was bombarded with letters from the French authorities expressing anxiety about the consequences of the move for public health and morals. The mayor of Granville-Ste-Honorine protested that the closure of maisons de tolérance would lead to an increase in "amateur" prostitution and a commensurate rise in VD among civilians. ${ }^{78}$ Nor was he untypical, for according to an article in the French Revue d'Hygiène, 66 out of 88 mayors recently surveyed favoured the maintenance of licensed brothels. ${ }^{79}$ The Commissioner of Police for Granville shared these concerns, and added that the closing of maisons to British troops would make prostitution harder to regulate. Such a ban, he warned, might also lead to an increase in illicit liaisons between British soldiers and members of the Women's Auxiliary Army Corps. The Commissioner's men had already surprised several couples who, as he put it, had "sacrificed themselves to Eros" in the undergrowth of Granville. ${ }^{80}$

The French sought to maintain a system of licensed prostitution for essentially the same reasons as the British (and also the Americans) had abandoned it: the need to reassure their citizens that the war would not result in moral or physical deterioration. Although the language of degeneration was highly complex, and varied enormously from one country to another, such concerns exercised a powerful influence on European politics prior to and during the war. ${ }^{81}$ Venereal disease, thought to be symptomatic of both moral and biological decline, was probably the single most important focus of such concerns between 1914 and 1918.

\section{The Medical Prophylaxis Debate}

The question of licensed prostitution was not, however, considered in isolation and was intimately bound up with the heated debate which surrounded medical prophylaxis. As MOs and many junior officers came to recognize the limitations of regulated prostitution,

76 PRO WO 32/5597: Cabinet minute, 18 March 1918; memo. by Sec. of State for War, 18 March 1918.

77 PRO WO 32/11404: Proceedings of InterAllied Conference on VD and its treatment, 11 July 1918. The Archbishop of Canterbury urged the French authorities to assist in preventing British troops from entering maisons de tolérance since considerable difficulty had been experienced in enforcing the ban.

78 PRO WO 32/5597: Le Maire, Granville-Ste.Honorine to Secretary of State, 24 June 1918.

${ }^{79}$ Faivre, op. cit., note 56 above, p. 677.
80 PRO WO 32/5597: Commissaire de Police de Granville to Le Maire, 28 June 1918.

${ }^{81}$ On degeneration and fears of national decline, see Pick, op. cit., note 5 above; Geoffrey Searle, The quest for national efficiency, Oxford University Press, 1971; Robert Nye, Crime, madness, and politics in modern France: the medical concept of national decline, Princeton University Press, 1984; Paul Weindling, Health, race and German politics between national unification and Nazism 1870-1945, Cambridge University Press, 1989; Claude Quetel, History of syphilis, trans. Judith Braddock and Brian Pike, London, Polity, 1990, pp. 176-210. 
they began to pin their hopes on disinfection, which was already routinely practised in the French Army. Modernizing MOs seeking to introduce prophylaxis had the enthusiastic backing of some civilians, especially doctors, but they also had their opponents. The intense debate conducted in the pages of British medical journals during 1917 and 1918 is indicative of the strength of feeling which the matter aroused. In a letter to the British medical Journal Dr H Bryan Donkin of London expressed the frustration felt by many medical men at being hampered by the "mediæval doctrine which is still operative in leading the public to regard sexual diseases from a different standpoint from that which they maintain towards all others". He believed that doctors were not only justified in spreading the knowledge they now possessed about VD, but that they had a duty to do so in view of their role as promoters of public health. ${ }^{82}$ His opinion was endorsed by scores of other practitioners, although there was, of course, considerable opposition from the NCCVD and religious bodies such as the Presbyterian Church. Their standard line of argument was that advocates of prophylaxis were degrading the medical profession by encouraging immoral behaviour. ${ }^{83}$

But support for medical prophylaxis also came from individuals in the Dominions, such as R B Rees, MP for Melbourne, who drew attention to the temptations which Australian soldiers faced in Britain and Egypt. ${ }^{84}$ The Dominions spawned vigorous campaigning organizations, such as the New Zealand Volunteer Sisterhood, with its outspoken secretary Ettie Rout. The Sisterhood, and the army MOs with whom it had established close links, aimed to combat the moralistic propaganda of the NCCVD, which it claimed was "hostile, obstructive and misinformed" on the subject of medical prevention. Rout and her supporters maintained that frank discussion about VD and prophylaxis was desirable, not only from a military point of view, but as the only realistic means of preventing further deterioration of the Anglo-Saxon race. ${ }^{85}$

By 1916 medical prophylaxis had gained the support of a good many British officers who were concerned about manpower economy. The Army Order of that year-in which soldiers who had exposed themselves to VD were directed to seek treatment within 24 hours at special disinfection units-was seen as a move in the direction of prophylaxis. But disinfection proved unpopular with the troops since the apparatus was installed in urinals and the procedure conducted in full view of other men. Neither was the system enforced, except in the British West Indian Regiment, which had exceedingly high rates of venereal infection. ${ }^{86}$

The disinfecting stations were a half-way house to the distribution of prophylactic packets; a practice already sanctioned in many other armies, including those of Britain's opponents. But when it permitted the establishment of disinfecting stations in 1916, the Army Council had to make it quite clear that it had no intention of moving towards personal prophylaxis, such was the strength of feeling against it in Britain. ${ }^{87}$ Yet, as with the question of licensed prostitution, it would be misleading to draw any sharp distinction between opinions held by soldiers and civilians. Military men such as Major Darwin, the

82 Br. med. J., 1917, i: 135-6.

$83 \mathrm{Br}$. med. J., 1917, i: 563, copy of a resolution passed by the Non-Subscribing Presbyterian Church of Ireland, Belfast.

${ }^{84}$ Br. med. J., 1917, i: 196-7, p. 196.
85 PRO WO 32/11403: Rout to Darwin, 15 June 1918.

86 MacPherson, et al., op. cit., note 33 above, p. 125 .

${ }^{87}$ Davenport-Hines, op. cit., note 4 above, p. 227. 
NCCVD's Treasurer, were prominent in the British purity movement, while other officers, as we have seen, were reluctant to condone measures which seemed to sanction immorality. There may have also been a feeling that ordinary soldiers were not to be trusted with the administration of prophylactics, such was the High Command's dim view of their ability to act independently.

No attempt was made to introduce personal prophylaxis in the British Army until 1918, when it was urged on the Army Council by the military venereologist $\mathrm{L}$ W Harrison. ${ }^{88} \mathrm{~A}$ severe manpower crisis, and demoralization following the successful German offensive of March 1918, meant that such appeals were now heard more sympathetically. ${ }^{89}$ But the Council was still under great pressure from purity organizations not to adopt the measure, and Dominion governments made it clear that they, too, were opposed to the practice. At the Imperial War Conference of July 1918 the New Zealand Prime Minister, Mr Massey, drew attention to the movement against prophylaxis that had emerged in his country. If prophylaxis were encouraged, he argued,

we are soon going to get into the position that other people have got into in days gone by, prior to the downfall of the country to which they belonged. Whenever an empire has fallen, the downfall has always been preceded by an orgy of immorality, and I am afraid ... we are getting perilously near that state of things in Great Britain. ${ }^{90}$

But prophylaxis had already been instituted in the New Zealand Army. It had evolved piecemeal in the ANZAC forces in Britain, France and Egypt during the first years of the war, and was sanctioned (albeit unofficially) by the military authorities. Unlike the British Army, those of the Dominions-operating far from home-were left to work out their own salvation unimpeded by the intervention of their respective purity movements. ${ }^{91}$

From early 1918, with VD rates still rising, the distribution of prophylactics also began (unsystematically) among British troops in the UK. The new Director General of the Army Medical Service, Surgeon-General Goodwin, told the 1918 Imperial Conference on VD that some 130,000 prophylactic tubes containing permanganate of potash had been distributed with good effect. ${ }^{92}$ However, the system did not become operative in all British stations until August 1918 and, overseas, until the last month of the war. Neither were individual supplies of prophylactics as generous as those in the New Zealand Army, for example, in which soldiers were provided with 6 tubes every time they went on leave. ${ }^{93}$

Declining VD admissions in the Dominion armies-though still higher than those of the British-seemed to provide some evidence that prophylaxis had reduced the military damage caused by these diseases. Admissions to hospital in the Canadian Army in the UK fell from a high of 222 per 1,000 in 1915 to 114 by 1917 , and 81 per 1,000 by 1918 .

88 PRO WO 32/5597: Sec. of Army Council to Sec. of State for War: "The Council cannot accept suggestions made with regard to prevention which would imply the adoption of any system of prophylaxis which might be said to afford opportunities for unrestrained vice".

${ }^{89}$ On the manpower crisis in early 1918 see R J Q Adams and P P Poirier, The conscription controversy in Great Britain, 1900-18, London, Macmillan, 1987, pp. 214-37.
90 PRO WO 32/11404: Procs., Imperial War Conference, 19 July 1918.

91 A G Butler, The Australian army medical services in the war of 1914-1918, vol. 3, Canberra, Australian War Memorial, 1943, p. 155; James Barrett, 'Management of venereal disease in Egypt during the war', Br. med. J., 1919, i: 125-7, p. 126. 92 PRO WO 32/11404, op. cit., note 90 above.

${ }^{93}$ Ellis, op. cit., note 32 above, p. 153. 
Among Australian troops in France, the admission rate fell from 85 to 64 per 1,000 in the last two years of the war. ${ }^{94}$ However, there were doubts over the contribution made by personal prophylaxis to this decline and, in the years after the war, senior figures in the AMS tended to favour disinfection by skilled attendants. Again, there was considerable doubt that ordinary soldiers could be relied upon to perform the procedure by themselves. $^{95}$

\section{The Purification of Egypt}

VD prevention in France had been shaped by a combination of military priorities and external political constraints. The political context was to be no less important in Egypt but, while public opinion in France served to maintain a system of regulated prostitution in the face of purity campaigners and the convictions of some senior British officers, in Egypt it contributed to a vigorous military crackdown on prostitution and associated forms of vice. The arrival of thousands of British, Dominion and Indian troops prior to campaigns in the Dardanelles and Palestine was viewed with trepidation by the military authorities. Egypt had a reputation not only as a land of plague and pestilence, ${ }^{96}$ but of vice and sensuality. There also existed vestiges of the belief that the climates of tropical or sub-tropical countries predisposed their inhabitants (including European visitors) to moral and physical decay. ${ }^{97}$ Anxieties within the British Army centred around two things: homosexuality and male prostitution, on the one hand ${ }^{98}$ (both of which were tolerated under Egyptian law); and native female prostitutes, on the other, who were considered especially disease-ridden and criminally inclined. ${ }^{99}$ In a memorandum of 1905 , Kitchener had warned troops that certain diseases,

when contracted by Europeans from natives of Asia and Africa are almost invariably fatal, for diseases passed on from one race to another always increase in severity. Similarly, syphilis contracted by Europeans from Asiatic women is much more severe than that contracted in England. It assumes a horrible, loathsome, and often fatal form through which in time . . the sufferer finds his hair falling off, his skin and flesh of his body rot, and eaten away by slow kankerous [sic] and stinking ulcerations. ${ }^{100}$

94 MacPherson, et al., op. cit., note 33, p. 118.

95 Ibid., p. 158. Papers of Capt. L Gameson, op. cit., note 54 above, p. 393.

96 European attitudes to the sanitary dangers of Egypt and its people are discussed in LaVerne Kuhnke, Lives at risk: public health in nineteenthcentury Egypt, Berkeley, University of California Press, 1990; Timothy Mitchell, Colonising Egypt, Berkeley and Los Angeles, University of California Press, 1991, pp. 117-18, 65-7, 98-9.

97 See Harrison, op. cit., note 12 above, ch. 2; Warner, op. cit., note 2 above, p. 156.

98 On military attitudes towards homosexuality see Jeffrey Weeks, Coming out: homosexual politics in Britain, from the nineteenth century to the present, London, Quartet, 1977, pp. 13-14, 18, 39; A N Gilbert, 'Buggery and the British navy, 1700-1861', J. soc. Hist., 1976-7, 10: 72-98; Hynes, op. cit., note 4 above, pp. 225-6: sodomy was punishable by a minimum of 10 years' imprisonment under martial law and a maximum of life. The homoerotic undercurrents of British military life are considered in Fussell, op. cit., note 51 above, pp. 272-309.

99 The nexus between race, sexuality and disease in colonial medical discourse is discussed in Sander L Gilman, Difference and pathology: stereotypes of sexuality, race and madness, Ithaca and London, Cornell University Press, 1985; Megan Vaughan, Curing their ills: colonial power and African illness, Cambridge, Polity, 1991, ch. 6; Frantz Fanon's description of the segregated colonial city in his The wretched of the earth, trans. Constance Farrington, Harmondsworth, Penguin, 1979, pp. 29-30.

100 Kitchener's memo to the British Army in India of 1905, quoted in Baynes, op. cit., note 53 above, p. 269. 


\section{Mark Harrison}

Kitchener's opinion was founded on the widespread belief that the inhabitants of Africa and Asia were morally inferior to Europeans, and Anglo-Saxons in particular. Like many medical men, he took the view that the virulence of the venereal "poison" increased the more degraded a woman became. ${ }^{101}$ This seemed to be underscored by the fact that VD rates were higher in Egypt than among troops stationed elsewhere. In 1912 the British Army at home suffered an average of 56.4 admissions to hospital from VD per 1,000 men; in India the rate was 55.5 and, in Egypt, 110.8 per 1,000. ${ }^{102}$

For many Egyptians the problem seemed to be quite the reverse. During the first years of the war there had been growing unease at the apparent rise in immorality in such cities as Alexandria. Although prostitution (both male and female) had long been tolerated in Egypt, it was fundamentally anti-Islamic, and there had been periodic reactions against it. ${ }^{103}$ In 1915, the influx of troops into Egypt fed a burgeoning trade in drugs, alcohol and prostitution. This angered the citizens of ports and garrison towns such as Alexandria, who were already sensitive to their city's reputation as the centre of the so-called "white slave trade". ${ }^{104}$ Foreigners, and now uncouth British and ANZAC soldiers, were identified as the main source of corruption in Egyptian society.

Before long Egyptians began to demand more protection against the contamination of their society by foreigners. The first shot in their purity campaign was fired in May 1915 when local newspapers took the Alexandria Corporation to task over its inaction against vice. As in many European countries, the question of morality was intimately bound up with fears of racial degeneration. And, in the case of the Islamic élite, with the rise of a more westernized, secular middle class, and the prospect of greater independence for women. The long-established Wadi-al-Nil newspaper was one of the most outspoken voices in the purity campaign. It felt that the time had come to speak out on "the moral situation in Egypt", since "the germs of immorality ... [had] begun to produce serious effects on some Egyptian families", frustrating all hopes of a "national renaissance of character". "The vices of civilization", it warned,

are threatening our dearest characteristics and even our existence. Our women folk used not to leave their houses except by permission of their guardians. Why should they now deviate from the traditional path, and adopt a blameworthy attitude which amounts to immorality in certain cases? ${ }^{105}$

This was also the view of the newspaper, al-Ahaly:

Vice is spreading terribly in this land in the form of secret agencies for the white slave traffic. We wonder how the authorities can allow such curses to exist in our midst ... It is a pity that an Islamic

101 Warner, op. cit., note 2 above, p. 157; Spongberg, op. cit., note 15 above, pp. 88-9; Levine, op. cit., note 12 above, p. 589.

102 Wellcome Institute for the History of Medicine (WIHM), RAMC 1212/9: Report of the Cairo Purification Committee, Cairo, Government Press, 1916.

103 Abdelwahab Bouhdiba, Sexuality in Islam, trans. Alan Sheridan, London, Routledge \& Kegan Paul, 1985, pp. 187-92.

104 A vast mythology surrounds the so-called "white slave trade" but there is only the barest evidence to suggest that the prostitutes involved had been sold or impressed into the trade against their will. The international movement of prostitutes, mainly from eastern and central Europe, was largely a consequence of poverty in these areas and of improved transportation. See Edward J Bristow, Prostitution and prejudice: the Jewish fight against white slavery, 1870-1939, Oxford, Clarendon Press, 1982; idem, op. cit., note 4 above, pp. 175-81.

105 Wadi-al-Nil, 25 May 1915. All vernacular Egyptian newspapers cited below have been accessed through reports on the native press in the Egyptian Gazette, and usually appear in that newspaper on the days following the date given for vernacular newspapers. 


\section{The British Army and Venereal Disease during the First World War}

country like Egypt, whose sharia forbids even betrothed people to see one another for the preservation of morality and honour, should appear as a country without any laws of morality and without rules to check the growth of such indecent practices. ${ }^{106}$

Alexandria's municipal Morality Department had been established prior to the war to deal with drug-dealing and prostitution, which had been condemned by the then Governor-General, Kitchener. ${ }^{107}$ The resolve with which the corporation pursued its campaign against vice was far too weak in the opinion of many traditionalists, but there were those among the indigenous population who saw the work of the department as counter-productive. Al-Ahram, a newspaper with a readership among the liberal Syrian immigrant community, argued that its pursuit of women of ill-repute led only to their being dispersed all over the city instead of in traditional red-light areas. "It would be far better", its editor wrote in March 1915, "if the Alexandria police recognised the impossibility of stamping out immorality by such absurd methods". ${ }^{108}$

\section{The Purity Campaign}

But towards the end of 1915 , the moral and national ${ }^{109}$ concerns of the Egyptian élite and those of the British military began to coalesce around the so-called "purification" of Alexandria and Cairo. Since the beginning of 1915 regulations for the control of prostitution had restricted it to licensed quarters of garrison towns such as Alexandria, Cairo, Port Said, and Ismalia. Each prostitute was inspected weekly by an official of the Public Health Department. Any woman with VD was forbidden from residing in a brothel and, in the case of Egyptian women, was sent to a lock hospital until cured. The police had no powers to send European prostitutes to hospital but could report a woman to her consul, who would then arrange for treatment at a European hospital. There was also "a better class of prostitute" living in respectable areas of Cairo, who had at first their own arrangements for inspection, but who were later inspected by the RAMC. ${ }^{110}$

Within twelve months it was clear that the system left much to be desired from a military point of view. Although admissions to hospital had fallen somewhat in the British Army, they were still higher than in any other British garrison. ${ }^{11}$ VD rates among

106 al-Ahaly, 14 June 1915.

107 Egyptian Gazette, 6 April 1915; 26 May 1915: 346 locals and 156 foreigners had been prosecuted for hashish smoking in Cairo during 1914.

108 al-Ahram, 16 March 1915.

109 Attempts to define and to control "normal" and "deviant" sexual practices are historically closely linked to the politics of nationalism. However, the concerns expressed by most Egyptians during the First World War should not be understood as "nationalistic" in the sense that they had a clear idea of an independent nation state. True "nationalist" politics was not prominent in Egypt until after the First World War, and in the years leading up to 1914 pan-Islamic sentiments were foremost in political debate, although there had been stirrings of secular liberalism. Thus, any sense of "national" character was closely intertwined with
Ottoman loyalties and a sense of Islamic (and sometimes Christian) identity. Indeed, much of the concern with "national character" stemmed from critical self-examination of the ills of Egyptian and Islamic society in the two decades preceding the war. See P J Vatikiotis, The history of modern Egypt from Muhammad Ali to Mubarak, London, Weidenfeld \& Nicolson, 4th ed., 1991, pp. 216-48; and George L Mosse, Nationalism and sexuality: respectability and abnormal sexuality in modern Europe, New York, Howard Fertig, 1985.

${ }^{110}$ Report of the Cairo Purification Committee, pp. $2-4$.

${ }^{111} \mathrm{~T} \mathrm{~J}$ Mitchell and G M Smith, History of the great war based on official documents. Medical Services: casualties and medical statistics of war, London, HMSO, 1931, p. 73. 
ANZAC troops were higher still and showed little sign of falling. The number of admissions among Australian troops increased slightly from 133 per 1,000 in 1915 to 137 in 1916. ${ }^{112}$ These figures caused consternation among the public in Britain and the Dominions, who were concerned not only about military efficiency but about a "material degeneration" among the civilian population once the troops were demobilized. ${ }^{113}$

Some British expatriates, Egyptians, and senior British officers also had serious moral reservations about the practice of licensed prostitution. They were profoundly uneasy with a system which so resembled the old CD Acts, and which seemed to encourage immoral behaviour. The attention of purity campaigners had been drawn to conditions in Egypt by such publications as With the ANZACS in Cairo, a sensationalist tract written by Captain Guy Thornton, a chaplain with the New Zealand Expeditionary Force. Thornton described a nightmare "inconceivably vile and horribly grotesque". He believed that there were over 2,300 licensed native prostitutes and 800 Europeans plying their trade in Cairo alone. British clergy also played a prominent part in the Egyptian purity campaign: in December 1915 the Anglican Bishop of Cairo and other prominent citizens (who had formed the Cairo Purification Society) presented a petition to the Commander-in-Chief: "We the undersigned residents of Cairo . . . call your attention once more to the existing conditions which menace the physical and moral health of thousands of soldiers in your command". The C-in-C promised to give the matter "careful consideration". 114

The upshot was the appointment in April 1916 of the Cairo Purification Committee, whose remit was to examine the working of existing regulations and to suggest other means for preventing infection of the troops. The Committee was a joint civil-military affair, being chaired by Lieutenant-General E A Altham, Inspector-General of Communications with the Egyptian Expeditionary Force, and including representatives from the city's Police and Public Health Departments, the High Commission, and the exiled Bishop of Jerusalem, Rennie MacInnes. ${ }^{115}$ Its members concluded that the system of licensed prostitution was undesirable from both a moral and a practical point of view. It believed that military discipline and the maintenance of moral standards among troops were indivisible, and that they were the most important factors in VD control. It was alleged that lower standards of discipline accounted for the higher incidence of VD among ANZAC troops. As the Committee put it:

The gallantry and devotion to duty of the Australian soldier in the face of the enemy cannot obliterate the fact that he belongs to a new Army raised in an incredibly short time and lacking the traditions of discipline and military order which the newly-raised units of the United Kingdom inherited by virtue of their connection with the old Regular Army. ${ }^{116}$

In the Committee's view, the moral drawbacks of a system which implicitly condoned prostitution were such that it could be justified only by a definite medical statement in its

\footnotetext{
112 Butler, op. cit., note 91 above, p. 187.

113 Br. med. J., 1916, ii: 668.

114 PRO WO 32/5597: extracts from With the ANZACS in Cairo by Chaplain-Captain Guy Thornton, NZEF.

115 Report of the Cairo Purification Committee, Cairo, Govt. Press, 1916, p. 1. The other members of the Committee were: Maj.-Gen. W A Watson (Commander of the EEF, Delta District); Bvt.-Col.
}

T W Gibbard (ADMS camps and troops, Alexandria); Col. Harvey Pasha (Commander of Police, Cairo); Dr H P Keatinge (representative of the High Commissioner); Dr J Ferguson-Lees (Public Health Dept., Cairo). The first meeting was held on 15 April 1916 and 12 more subsequently in 1916.

116 Ibid., p. 5. 
favour. But no such statement was forthcoming: witness after witness told the Committee that the regulations had been easily circumvented. Colonel Barrett of the Australian Army Medical Corps pointed out that "many infected women, when the doctor is coming round, can generally escape detection in these examinations. They clean themselves [on the advice of midwives] and are up to all sorts of devices and can manage to pass the examination". Colonel Sullivan, RAMC, agreed, and said that this had also been his experience in India, where a similar system operated. More importantly, licensed prostitution had created "the idea among a large body of men that it gives security against venereal disease". 117

The Purification Committee-together with a separate committee of the Egyptian Government-proposed an alternative course of action more firmly based on "moral" principles. The programme of action had two dimensions: a crackdown on all forms of vice and a more vigorous inculcation of moral principles among the troops. In language which anticipated the controversial amendment to the British Defence of the Realm Act in $1918,{ }^{118}$ the Committee recommended that it be made an offence for any person knowingly to convey venereal disease to another, contravention of which "should be visited with severe punishment". The military and civil authorities would be empowered to arrange for the compulsory examination, and detention in hospital if necessary, of all women suspected of having VD. ${ }^{119} \mathrm{~A}$ host of other measures, many of them unprecedented in Egypt, were also recommended. These included the prohibition of "indecent dances"; the arrest and detention under martial law of persons guilty of sodomy (not recognized as an offence under Egyptian civil law); the arrest and punishment of pimps; the suppression of adverts by "venereal quacks"; and a ban on the sale of alcohol in red light districts between 5 p.m. and 8 a.m., alcohol being a notorious "incentive to immorality". 120

\section{The Purification of Cairo and Alexandria}

The so-called "purification" of Cairo got under way in the summer of 1916. What distinguished it from the work of the municipal Morality Departments was not only the extent of the new regulations, and the vigour with which they were enforced, but the fact that many of the offences were now tried under martial rather than civil law. The first sitting of the Military Summary Tribunal at Cairo, which took place on $3 \mathrm{July}$, was by all accounts a high-profile affair: the public were admitted to the proceedings, and they were reported in the local press. The defendant was an Egyptian-one Abdul Salim Hassanaccused of tempting two British corporals to a house of ill-fame. The prosecution rested on the testimony of the two corporals who, unluckily for Hassan, were military policemen. Hassan was sentenced to 12 strokes of the Kourbash. ${ }^{121}$

\footnotetext{
117 Ibid., p. 7.

118 Regulation 40D of the Defence of the Realm Act was introduced in Britain after pressure from Dominion governments. It made it an offence for any infected woman to have sexual intercourse with a member of $\mathrm{HM}$ armed forces. $40 \mathrm{D}$ was vigorously attacked by moral and feminist campaigners, and only a limited number of prosecutions were made
}

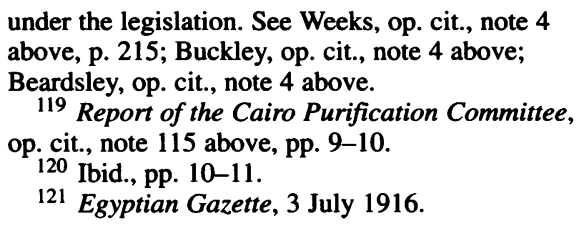




\section{Mark Harrison}

The volume of prosecutions in the coming months was such that the Cairo police established a special "reformatory" for those imprisoned for "immoral activities". The building was capable of holding some 3,000 to 4,000 prisoners who would be taught trades and useful skills to wean them away from a life of vice. These moves were warmly welcomed in the local press. Even the liberal, Christian al-Ahram, which had previously been sceptical about the value of the Morality Department, gave the measures its full support. "The authorities deserve every praise", wrote its editor, "for the activity which they have displayed in the purification of Cairo". ${ }^{122}$ The traditionalist al-Ahaly of Alexandria also noted with satisfaction that English law dealt severely with "immorality". It claimed that "the Military Court in question is now more competent to deal with such cases than the ordinary Egyptian law courts", and hoped that the regulations, and trial by martial law, would be extended to Alexandria. ${ }^{123}$ Martial law also dealt with non-British and non-Egyptian subjects, who had hitherto been under the jurisdiction of their respective national governments whilst in Egypt. ${ }^{124}$

By the end of July the "purification" of Alexandria, too, was in full swing. A new order closed down drinking houses in the Clot Bey and Wagh-al-Birket areas after 5 p.m. The Egyptian Gazette reported approvingly that these districts were "gradually losing all animation and the innumerable houses of ill-fame in the neighbourhood have lost the greater part of their clients". However, many tenants were apparently contemplating a move to districts of the city still untouched by the licensing restrictions. ${ }^{125}$ The newspaper Wadi-al-Nil hoped that measures would be extended to include all bars so that civilians might be protected as well. ${ }^{126}$

Restrictions on alcohol sales were accompanied by a crackdown on other forms of intoxication associated with immorality. Until the mid-1880s there were no restrictions on hashish smoking in Egypt, when the Governor-General Lord Cromer outlawed the activity and appointed coastguards to prevent hashish from being smuggled into Egypt. However, the attempt to ban the smoking of hashish seems only to have increased its popularity, and the practice spread among sections of the middle class who came to look upon it as a form of "cultural resistance". The traditionalist Islamic newspapers al-Akhbar and al-Ahaly, however, welcomed the extension of military law to cover hashish smoking and smuggling, for the civil authorities had hitherto been lax in prosecuting such cases. ${ }^{127}$

The military authorities had no such reservations. Reporting a conversation between two habitual hashish smokers, the Cairo newspaper al-Mahrussa pointed out that such men were far more afraid of the military authorities than of the police, for the latter were easily corrupted. In one instance, the military had raided a hashish den only to find a host of "respectable" citizens-including a police corporal-smoking the substance. ${ }^{128}$ Over the next two years such raids were made frequently. In one crackdown on hashish and narcotics in Alexandria in 1917 some 92 "native cafés" were raided and many persons prosecuted under martial law. ${ }^{129}$

Cocaine use was also feared among European troops in Egypt, and was closely associated in the military mind with prostitution and moral laxity. According to the

122 al-Ahram, 24 July 1916.

123 al-Ahaly, 14 July 1916.

124 Bristow, op. cit., note 4 above, p. 181.

125 Egyptian Gazette, 17 July 1916.
126 Wadi-al-Nil, 7 August 1916.

127 al-Akhbar, 19 July 1916.

128 al-Mahrussa, 28 August 1916.

129 Egyptian Mail, 3 March 1917. 
Egyptian Mail of Cairo, "Soldiers have been seen literally to crawl in weakness and agony . . . into a shop where the deadly 'snow' might be obtained; and to emerge from it reinvigorated for an hour or two like new men". The agents were supposed to be mostly foreigners and the distributors mainly prostitutes. The incidence of the problem was probably exaggerated by a British and Egyptian press eager to see the city cleansed, but there is some evidence of cocaine use by soldiers outside Egypt, too. The Egyptian Mail referred to the trial in London of a Canadian addict - an officer-who had apparently killed a sergeant while under the influence of the drug. Cocaine was also available in the fleshpots of Bombay and other Indian ports. ${ }^{130}$

Although the purification of Egypt was conducted with great enthusiasm, there were clearly limits to its effectiveness. Soldiers and prostitutes could always find a way round the restrictions, and many of the latter simply moved to unregulated areas. In view of this, the crackdown on vice was accompanied by an intensification of moral education among the troops, mirroring the course of action taken in France. ${ }^{131}$ The Cairo Committee's ultimate goal was "the establishment of a moral standard amongst officers and men, which would regard as breaches of military duty acts involving wilful exposure to venereal disease". ${ }^{132}$ Its members were particularly concerned about the absence of such standards among officers. The Committee had heard

that the habit of fornication is more prevalent amongst officers than amongst the rank and file ... they consider that Commanding Officers should be warned that their first duty in the fight against venereal disease is to introduce amongst their officers, if it does not already exist, a tone which regards illicit intercourse with women, not as a harmless and excusable pastime, but as an offence against the body, foreign to the best tradition of English manhood-as, in fact, "bad form". ${ }^{33}$

The control of VD was thought to require a reaffirmation of the pre-war ideal of masculine purity, stiffened by a greater sense of obligation on the part of the soldier to his comrades-in-arms.

This was not simply cant for the consumption of the purity lobby, for the report was confidential. Senior officers such as Kitchener and Lieutenant-General Altham were concerned about moral decline in British society, as well as the public image of the Army as expressed through the conduct of its soldiers. More especially, high rates of VD among officers (and also among Army chaplains) called into question traditional notions of chivalry and moral virtue, which had previously been important in distinguishing between classes, and between officers and other ranks.

The importance of such concerns in shaping VD control in Egypt is further demonstrated by the debate over medical prophylaxis. Although the Cairo Purification Committee felt that all steps taken to prevent VD should "bear close regard to moral as well as physical principles", it was recognized that the attainment of an appropriate standard of morality was unlikely in the short term and that other measures ought to be investigated. ${ }^{134}$ These included medical prophylaxis: after giving "anxious

\footnotetext{
130 Egyptian Mail, 2 August 1916. Cocaine was allegedly smuggled into various parts of the British empire by Austrian, German and other foreign steamship lines. See Br. med. J., 1916, i: 391.

131 PRO WO 32/5115: Annual Report on Infectious Diseases in the British Army in France.
} 


\section{Mark Harrison}

consideration" to the subject, the Committee concluded that there were strong moral objections to compulsory prophylaxis but that prophylactics should be made available to soldiers upon payment. ${ }^{135}$

But the Committee's recommendation was made with reluctance and three of its members dissented from the majority decision. The Bishop of Jerusalem, Major-General Watson (Commander of the Delta District) and Colonel T W Gibbard, RAMC, opposed prophylaxis on the grounds that it was

not only in direct contradiction to the main principle on which we take our stand, namely, that the moral is the most important factor in the prevention of venereal disease, but would actually defeat the ends we have in view, for it would convey the idea that the military authorities consider immorality unobjectionable ... It would almost certainly lead to an increase in the number of men exposing themselves to infection, with a consequent increase in disease. ${ }^{136}$

The inclusion of Gibbard-who had made his reputation during the Salvarsan trials of 1911 - among those who dissented from the majority report, suggests that it would be misleading to draw any sharp distinction between "moral" and medical standpoints on the question of VD control. The purity lobby was clearly a force to be reckoned with within the Army as well as in civilian life, and medical officers were not exempt from its influence. But Gibbard's views were probably untypical of medical officers as a whole, since they were more often the champions of prophylaxis than its opponents. One of the most prominent advocates of prophylaxis in Egypt was Colonel Barrett, an Australian Army MO in Port Said. Barrett, and the Base Commandant Colonel Elgood, were unimpressed by the effectiveness of either repressive measures or licensed prostitution. They recommended a mixture of prophylaxis, "moral" education and regulated prostitution which was to become the model for VD control in Egypt during the last year of the war.

\section{Conclusions}

Attempts to control venereal disease in the British Army during the First World War were a peculiar, and none too effective, amalgam of moralism and pragmatism. Senior British officers, including some medical men, were reluctant to embrace preventive measures which seemed to condone immoral behaviour, despite medical pronouncements in their favour. Thus, medical prophylaxis against VD was introduced far more slowly, and less extensively, than in the armies of Britain's allies, or those of its opponents. Educational efforts to curb VD were also heavily moralistic, while the treatment of these diseases was never freed from penal stigma, with much concealment taking place as a result.

If not peculiar to the British, the equation of military virtue with sexual restraint was far less evident in the armies of France, Germany and the Dominions. This was probably a reflection of the strength of women's and purity organizations in Britain, but also of the British Army's distinctive history which was closely intertwined with that of movements for moral reform. Although purity campaigners and the Army had been at loggerheads over the CD Acts, influential military men from Gordon to Kitchener had aligned

135 Ibid., p. 12.

136 Ibid., p. 17. 
themselves with moral reformers in civilian life. Indeed, the popularity enjoyed by these men, and the increasing esteem in which the Army was held in the late-nineteenth century, owed much to the fact that the military was seen to embody the moral values prized by the Victorian and Edwardian middle class. The new armies raised in the Dominions lacked these traditions, as did those of France and Germany. The American campaign against VD, however, reflected the concerns of Progressive politicians in the United States, for whom modernization and morality were closely intertwined. ${ }^{137}$

Although licensed prostitution was anathema to many British commanders, as well as civilian campaigners, the political situation in France was such that even stern moralists like Haig were forced to accept the existence of maisons de tolérance. Only the threat of declining public support for the war in Britain, and the party-political implications of ignoring the feminist and purity lobbies, led to maisons being placed out of bounds to British troops. In Egypt, however, indigenous élites and the British expatriate community had the ear of elements within the Army which sought a "moral" basis for VD control. The "moral consensus" reached in Egypt resulted in severe restrictions being placed on prostitution, and an unprecedented crackdown on associated forms of vice. Civilian purity organizations and sections of the British Army also worked together against the introduction of medical prophylaxis; just as many civilian doctors and military medical officers united to campaign in its favour.

These alliances suggest that it is erroneous to draw sharp distinctions between civilian and military attitudes towards VD control. Rather, we have seen a series of negotiations between civilians and the military, and between rival factions in the Army itself. These alliances were fluid and dynamic, and positions on VD control were never exclusive or inflexible. The political climate was all important: different contexts served to amplify or muffle personal predilections. However, certain patterns do emerge. First, there was a slow drift away from reliance solely on either "moral" control or regulated prostitution, and a tendency to combine both, increasingly with the addition of prophylaxis. Secondly, certain generalizations can be made about those who took up different positions in the VD debate. Most, but not all, medical officers tended to emphasize prophylaxis rather than moral restraint. This was also true of most officers on the ground, as opposed to senior staff, who were generally less well acquainted with the needs of their men. The latter were also older and probably more likely to harbour Victorian notions of military virtue and sexual continence.

This preoccupation with "good form" reflected general assumptions about class differences, and the greater gallantry and self-discipline usually expected of officers. It is noticeable that padres in VD hospitals tended to single out young, "well-bred" soldiers as objects for moral instruction, rather than rankers drawn from the working class. Equally, what most concerned the Purification Committee in Egypt was the apparent decline of moral standards among officers, and the consequent erosion of assumed distinctions between them and other ranks. Thus, venereal disease presented a conceptual problem, as much as a managerial one.

But although VD may have had a social levelling effect, it served to compound ethnic prejudices; be they the stereotype of the "unclean native", or the "undisciplined colonial".

137 Brandt, op. cit., note 62 above, pp. 52-95. 


\section{Mark Harrison}

The same could be said of military attitudes towards women. Just as many purity organizations continued to portray VD as a "military disease", so the Army persisted in its assertion that the disease was primarily an evil of civilian society, or more particularly of "loose women". Yet for all its public rhetoric, the problem of VD prevention in the British Army was always conceived as much in terms of the "immoral" or "ignorant" soldier, as it was of the "scarlet woman". 